\title{
Hookworm-related Cutaneous Larva Migrans with Exceptional Multiple Cutaneous Entries
}

\begin{abstract}
Keywords: Hookworm-related Cutaneous Larva Migrans: Hookworm; Serpiginous multiple tracks; Tropical area; Anti-parasite agent

Abstract

Hookworm-related Cutaneous Larva Migrans ( $\mathrm{HrCLM}$ ) is a pruritic serpiginous cutaneous eruption caused by animal hookworms commonly found in tropical and subtropical areas, especially the Southeastern United States. We describe here a very exceptional HrCLM case showing multiple larva entries/lesions in a 63-yearold white male living in Miami. Clinically he presented with multiple pruritic erythematous serpiginous tracks on his left anterior leg, left calf, and right thigh. While skin biopsies failed to demonstrate larva itself, the overall histological features supported multiple larva tracks as showing several small intra-epidermal cavities with eosinophil-rich dermal inflammation. The patient was treated with Ivermectin 200 $\mathrm{mcg} / \mathrm{kg}$ daily per OS for 2 days, and his cutaneous lesions subsided within 1 week of the treatment. This case exemplifies that even though the clinical presentation of HrCLM is extensive with multiple cutaneous larva tracks, it is still should be treated with a broad-spectrum antiparasitic agent at normal dosage. We also discuss literature-based characteristic geographical and clinical features of $\mathrm{HrCLM}$ and treatment options.
\end{abstract}

\section{Introduction}

Hookworm-related Cutaneous Larva Migrans (HrCLM) is one of the most common helminthic skin infestations. HrCLM is caused by the larvae of domestic animal hookworms, the most common being Ancylostoma braziliense and Ancylostoma caninum [1-3]. The mature hookworms reside in the intestines of cats and dogs and their eggs are released into the environment on defecation. Within two days the larvae hatch and mature to filariform (third stage) larvae able to infect other animal hosts [4]. These larvae are most prevalent in tropical and subtropical areas, frequently found on beaches in the Southeastern United States, Central and South America, Southeast Asia, and Africa $[2,5]$. Humans are infected via contact with these larvae through soil. Sites that are the most commonly affected include feet, legs, and buttocks $[3,6]$. The filariform larvae in humans are not capable of maturation, usually with one single entry, and only migrate within the epidermis of immunocompetent people. The first sign may be a pruritic papule that evolves to the classic serpiginous erythematous track (i.e. "creeping eruption"). The larval migration triggers severe pruritus that may result in epidermal disruption and secondary infection, requiring treatment. The diagnosis is made by physical examination and history, such as occupational history or endemic areas travel; and skin biopsy is commonly not necessary [4,7].

Here, we present an exceptional HrCLM in a Miami resident with multiple larva entry points on three different locations of the body. We also discuss literature-based characteristic geographical, clinical and histological features of HrCLM, and treatment options.

\section{Journal of}

\section{Clinical \& Investigative} Dermatology

Luis J. Borda', Penelope J. Kallis', Robert D. Griffith ${ }^{1}$, Alessio Giubellino ${ }^{1}$ and Jeong Hee Cho-Vega ${ }^{2 *}$

${ }^{2}$ Department of Dermatology and Cutaneous Surgery, University of Miami Miller School of Medicine, Miami, FL, United States

${ }^{2}$ Dermatopathology Division, Department of Pathology and Laboratory Medicine, Sylvester Comprehensive Cancer Center and University of Miami Miller School of Medicine, Miami, FL, United States

\section{*Address for Correspondence}

Jeong Hee Cho-Vega, Dermatopathology Division, Department of Pathology and Laboratory Medicine Sylvester Comprehensive Cancer Center and University of Miami Miller School of Medicine 1120 NW 14th Street, Holtz ET, Suite 2146 Miami, FL 33136, USA, Tel: (305)243-6433; Fax: (305)-243-1624; E-mail: j.cho1@med.miami.edu

Submission: 25 May, 2017

Accepted: 15 June, 2017

Published: 22 June, 2017

Copyright: @ 2017 Borda LJ, et al. This is an open access article distributed under the Creative Commons Attribution License, which permits unrestricted use, distribution, and reproduction in any medium, provided the original work is properly cited.

\section{Case Presentation}

A 60-year-old white male, who came from a rehabilitationassisted living facility in Miami, Florida, presented with multiple intensely pruritic migratory erythematous serpiginous tracks for 10 days over his left calf, left anterior leg, and right thigh. There were also hyper-pigmented macules around the tracks with overlying crust (Figure 1). Patient stated that he had been living some time in a bush and sleeping on the ground where stray animals defecate. He was previously treated for scabies with permethrin without success, otherwise unremarkable medical history. Based upon the typical characteristics of the lesions and epidemiologic history, a diagnosis of HrCLM was suspected, but due to the unusual multiple lesions, skin punch biopsies were performed from the left buttock and right posterior lower leg. Histologic sections showed several small intraepidermal cavities, likely corresponding to larva tracks (Figure 2A) associated with eosinophil-rich dermal mixed inflammatory cell infiltrates (Figures $2 \mathrm{~B}$ and $2 \mathrm{C}$ ). Histology failed to demonstrate larvae itself. However, given the characteristic clinical presentation and overall histological features, the diagnosis of HrCLM was made.

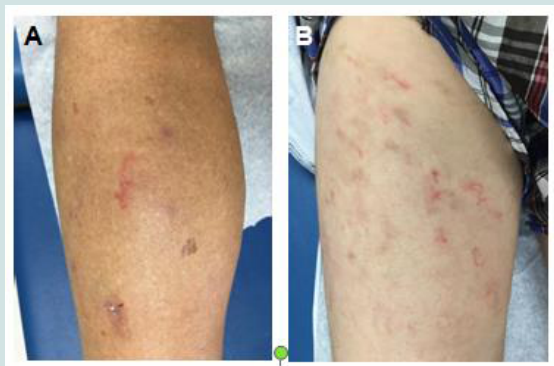

Figure 1: Clinical presentation. Erythematous serpiginous larva tracks associated with hyper-pigmented macules and crusts. (A) Posterior surface of right calf. (B) Right anterior thigh. 
Citation: Borda LJ, Kallis PJ, Griffith RD, Giubellino A, Cho-Vega JH. Hookworm-related Cutaneous Larva Migrans with Exceptional Multiple Cutaneous Entries. J Clin Investigat Dermatol. 2017;5(1): 4

Initial treatment was aimed at eradication of the hookworm larvae. He was treated with Ivermectin $200 \mathrm{mcg} / \mathrm{kg}$ PO daily for 2 days (15 $\mathrm{mg}$ PO the first day and $15 \mathrm{mg}$ PO the second day) and triamcinolone $0.1 \%$ ointment twice daily for pruritus. The lesions subsided after one week with treatment.

\section{Discussion}

HrCLM is one of the most frequent cutaneous parasitic infestations seen among people living in tropical and subtropical areas, including Southeastern Florida [2,3,8]. This dermatosis was described for the first time in 1874 as "creeping eruption" [2,3]. HrCLM is caused by the inadvertent penetration and migration of animal hookworm larvae through the epidermis. The most common parasite species include Ancylostoma braziliense (hookworm of wild cats, and domestic cats and dogs) and Ancylostoma caninum (dog hookworm) [9]. The adult worms thrive in the intestines of their definitive host (cats and dogs) and release their eggs into the environment via defecation. These eggs mature in the soil, protected from desiccation and intense temperatures, from first to third stage larvae (filariform larvae) capable of infecting other animal hosts through skin penetration (Figure 3) [4]. Warm, humid and shady fields, sand piles or seashores are especially favored areas, therefore making farmers, gardeners or beach visitors prone to acquiring the infestation occupationally or accidentally [10]. In the case of our patient, there was a history of homelessness and residence in Miami prior to presentation. The time of incubation has not been specified, but an incubation time of several days to a month is commonly seen $[7,11,12]$. The parasites infect humans as incidental hosts via direct contact with infested areas by walking and standing on the sand. Contrary to their presence in the definite host, the filariform larvae in humans are unable to mature, and instead migrate aimlessly, confined to the epidermis and sometimes the upper dermis [3]. These larvae migrate at the rate of 1 to $2 \mathrm{~cm}$ per day with a half-life between 2 to 8 weeks [2-4]. Jackson et al. found that the length of the eruption track was associated with the duration of the infestation, with a rate of $2.7 \mathrm{~mm}$ increase in length per day therefore time of exposure can be calculated [13]. In our patient with multiple tracks and entry points, the longest track was no more than $50 \mathrm{~mm}$, indicating an incubation period less than 20 days.

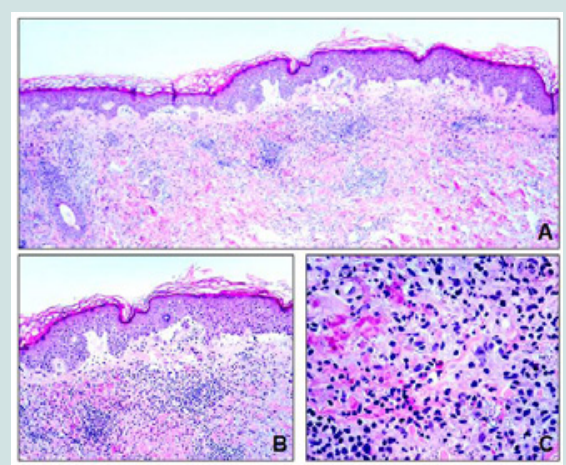

Figure 2: Larva tracks and mixed dermal infiltration of eosinophils, neutrophils, lymphocytes, and histiocytes. (A and B) A sub-epidermal cleft, potentially corresponding to the larva tracks. No definitive parasites were observed (A, $H \& E, x 4 ; B, H \& E x 10)$. (C) The inflammatory infiltrate is composed of a mixed cell population including numerous eosinophils, neutrophils, lymphocytes, plasma cells, and histiocytes forming subtle granulomatous reaction (H\&E, x40).
After the filariform larvae penetrates and migrates within the epidermis by enzymatic digestion of keratin, a local inflammatory reaction develops, distinguished initially by a pruritic papule that develops into a pruritic serpiginous erythematous track 1 to 6 days after inoculation $[2,4,10]$. The tracks left by the larvae during migration desiccate and then become filled with a scab $[2,3,14]$. Vesicles, papules and crusts frequently appear along the track. Impetigo may result following secondary bacterial infection from scratching due to intense pruritus [10]. The most commonly affected regions are the dorsum of the feet; legs and the buttocks less commonly. Lesions on the anterior abdominal wall and penile shaft may occur rarely; but any part of the body in contact with the larvae can be involved (Table 1) $[2,10,15]$. Most of previously reported cases showed a single-entry point of larva infestation and like seen in our case, multiple entries in different anatomic sites are less common (Table 1). This unusual presentation might lead to an inappropriate and/or delayed intervention [16]. Cough, wheezing, and chest pain may occur rarely, and pulmonary eosinophilia (Loeffler's pneumonia) occurs sometimes in patients with allergic diseases [10].

The diagnosis of HrCLM is usually made purely by history and physical examination [17]. Peripheral eosinophilia may be transient and concomitant with migratory pulmonary infiltrates or elevated serum IgE titers, but it is of minor help for diagnosis. Skin biopsy is generally not needed but displays mainly eosinophilic infiltration and larva are infrequently seen. Confocal scanning laser microscopy has shown to be an effective method to locate the larval burrow, trace and locate the HrCLM for removal $[4,18]$. Although the efficacy of dermoscopy has not been established, it may help detect the translucent, brown formless tracks correspondent to the larval body and red-dotted vessels corresponding to an empty burrow $[4,19]$. Currently, optical coherence tomography is being used to locate the larva for extraction [10].

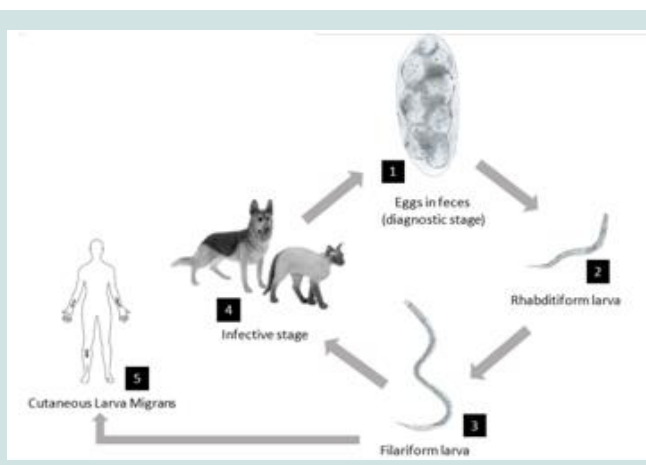

Figure 3: Life cycle of $A$. braziliense/caninum. A. braziliense and A. caninum are the most common hookworms species that cause Cutaneous Larva Migrans (CLM). (1) Eggs mature in the soil under favorable conditions (protected from desiccation and intense temperatures); rhabditiform larvae hatch 1 to 2 days. (2) In either feces or soil, the rhabditiform larvae develop to a third stage larvae (filariform larvae) after 7 to 10 days. (3) When these infective larvae get in contact with their definitive host (dogs and cats). (4) They penetrate the skin being transported via blood stream to the heart and then to the lungs. After penetrating the pulmonary alveoli wall, the larvae are propelled by cilia up through the bronchial tree until the pharynx. Then, larvae are swallowed and deposited in the small intestine. On the intestinal mucosa, they become sexually mature adults. Attached from the lumen of the small intestine, a single female worm produces between 200 to 6000 eggs daily, which are released through defecation. (5) The filariform larvae infect humans as incidental hosts via direct contact. However, after skin penetration, the filariform larvae cannot transfer to the heart and lungs for maturation, and instead migrate aimlessly within the epidermis. 
Citation: Borda LJ, Kallis PJ, Griffith RD, Giubellino A, Cho-Vega JH. Hookworm-related Cutaneous Larva Migrans with Exceptional Multiple Cutaneous Entries. J Clin Investigat Dermatol. 2017;5(1): 4.

Differential diagnosis includes other creeping eruptions (i.e. larva currens, gnathostomiasis), subcutaneous swelling lesions (i.e. scabies and myasis), allergic contact dermatitis, and tinea pedis [20,21]. In larva currens, Strongyloides stercoralis also causes a serpiginous track; however, the larval path migrates faster at a rate of $5-10 \mathrm{~cm} / \mathrm{h}$ compared with the 1-2 cm/day from the cat or dog hookworm. The serpiginous track is an urticarial wheal bounded by an itchy flare that lasts a couple of hours [16]. Contrary to HrCLM, contact to the larvae of Ancylostoma duodenale or Necator americanus leads to a pruritic, papulo-vesicular rash called "ground itch" [22]. Gnathostomiasis is an infection that travelers may get in Southeastern Asian countries and triggered by a nematode acquired by the human consumption of inappropriately cooked amphibians or shellfish. The migratory and serpiginous track is longer and more swelling is associated than that of dog and cat hookworm. Furthermore, gnathostomiasis histology is consistent with eosinophilic panniculitis (deep dermis) $[16,20]$.

Although HrCLM is self-limited, treatment with anti-helminthic agents is generally recommended due to possible complications (e.g. secondary bacterial infection and allergic reactions) in conjunction with the severe pruritus (Table 1) [2,17,21]. Albendazole and ivermectin are acceptable as first-line treatments; however, topical treatment is another alternative. Administration of 400 units/day oral dose of albendazole for 3 to 7 days results in cure rates of 80 to $100 \%$ [8]. Some potential side effects include headache and increased liver

Table 1: Literature-based clinical characteristics of cutaneous larva migrans.

\begin{tabular}{|c|c|c|c|c|c|c|c|}
\hline Authors, (Year) & $\begin{array}{l}\text { Age(years) } \\
\text { /Sex }\end{array}$ & $\begin{array}{l}\text { Geographic } \\
\text { Region }\end{array}$ & $\begin{array}{l}\text { Anatomic } \\
\text { Location }\end{array}$ & Clinical Presentation & Histology or Imaging & Treatment & Prognosis \\
\hline $\begin{array}{c}\text { Roest et al. [25] } \\
\text { (2001) }\end{array}$ & $47 / \mathrm{M}$ & United Kingdom & Right Buttock & $\begin{array}{l}\text { Erythematous plaque } \\
\text { with serpiginous } \\
\text { urticated tracks at the } \\
\text { periphery. }\end{array}$ & $\begin{array}{c}\text { Histology: } \\
\text { Intraepidermal } \\
\text { blister and } \\
\text { eosinophilic dermal } \\
\text { infiltrate. }\end{array}$ & $\begin{array}{l}\text { Oral albendazole } 400 \\
\text { mg/day for } 1 \text { week. }\end{array}$ & $\begin{array}{l}\text { Marked resolution } \\
\text { after } 7 \text { days. }\end{array}$ \\
\hline $\begin{array}{c}\text { Malvy et al. [16] } \\
(2006)\end{array}$ & $42 / \mathrm{M}$ & Thailand & $\begin{array}{l}\text { Left abdomen } \\
\text { and left thigh }\end{array}$ & $\begin{array}{c}\text { Several serpiginous } \\
\text { tracks, follicular } \\
\text { papules, vesicles, and } \\
\text { burrows. }\end{array}$ & $N / A^{*}$ & $\begin{array}{l}\text { Single oral dose of } \\
\text { ivermectin } 12 \mathrm{mg} \text {. }\end{array}$ & $\begin{array}{l}\text { Complete resolution } \\
\text { within first } 10 \text { days. }\end{array}$ \\
\hline $\begin{array}{c}\text { Siriez et al. [12] } \\
(2010)\end{array}$ & 6/M & Brazil & $\begin{array}{l}\text { Right foot } \\
\text { Right foot }\end{array}$ & $\begin{array}{c}\text { Single serpiginous } \\
\text { erythematous track of } \\
\text { the sole. } \\
\text { Single erythematous } \\
\text { track on the external } \\
\text { side. }\end{array}$ & N/A & $\begin{array}{l}\text { Oral ivermectin (3 mg). } \\
\text { Oral ivermectin ( } 6 \mathrm{mg} \text { ). }\end{array}$ & $\begin{array}{c}\text { Complete resolution } \\
\text { after } 8 \text { days } \\
\text { Complete resolution } \\
\text { (date unspecified) }\end{array}$ \\
\hline $\begin{array}{c}\text { Gutte et al. [14] } \\
(2011)\end{array}$ & $12 / \mathrm{M}$ & India & Dorsal left foot & $\begin{array}{l}\text { Single erythematous } \\
\text { track with dermatitis }\end{array}$ & $\mathrm{N} / \mathrm{A}$ & Unknown & Unknown \\
\hline $\begin{array}{c}\text { Purdy et al. [15] } \\
\text { (2011) }\end{array}$ & $38 / \mathrm{M}$ & Mexico & Right foot & $\begin{array}{l}\text { Single erythematous } \\
\text { serpiginous eruption. }\end{array}$ & $\begin{array}{l}\text { Confocal microscopy: } \\
\text { epidermal } \\
\text { dark disruption } \\
\text { corresponding to a } \\
\text { larval burrow. } \\
\text { Histology: richly } \\
\text { eosinophilic, intact } \\
\text { hookworm larva within } \\
\text { the epidermis. }\end{array}$ & Thiobendazole & $\begin{array}{l}\text { Resolved following } \\
\text { removal of larva } \\
\text { with } 4 \mathrm{~mm} \text { punch } \\
\text { biopsy extraction }\end{array}$ \\
\hline $\begin{array}{c}\text { Tekely et al. [3] } \\
\text { (2013) }\end{array}$ & $2 / F$ & Brazil & Right heel & $\begin{array}{l}\text { Single, slightly } \\
\text { raised erythematous } \\
\text { serpentine lesion }\end{array}$ & $\mathrm{N} / \mathrm{A}$ & $\begin{array}{l}\text { Oral albendazole (200 } \\
\text { mg/day for } 3 \text { days), } \\
\text { freezing of leading } \\
\text { edge with solid carbon } \\
\text { dioxide. }\end{array}$ & $\begin{array}{c}\text { Complete resolution } \\
\text { within few days }\end{array}$ \\
\hline $\begin{array}{c}\text { Kudrewicz et al. } \\
\text { [2] (2015) }\end{array}$ & $31 / F$ & Caribbean & Right foot & $\begin{array}{l}\text { Single erythematous, } \\
\text { scaly, serpiginous } \\
\text { indurated plaque in a } \\
\text { pregnant woman }\end{array}$ & $\mathrm{N} / \mathrm{A}$ & $\begin{array}{l}2 \text { cycles of liquid } \\
\text { nitrogen }\end{array}$ & $\begin{array}{c}\text { Complete resolution } \\
\text { within } 6 \text { days }\end{array}$ \\
\hline $\begin{array}{c}\text { Baple et al. [7] } \\
(2015)\end{array}$ & $68 / F$ & $\begin{array}{l}\text { United Kingdom } \\
\text { United Kingdom }\end{array}$ & $\begin{array}{l}\text { Right hand } \\
\text { Right foot }\end{array}$ & $\begin{array}{c}\text { Single erythematous } \\
\text { track }\end{array}$ & $\mathrm{N} / \mathrm{A}$ & $\begin{array}{l}\text { Single oral dose of } \\
\text { albendazole }(400 \mathrm{mg})\end{array}$ & $\begin{array}{c}\text { Complete resolution } \\
\text { after } 1 \text { week }\end{array}$ \\
\hline $\begin{array}{c}\text { Purkait et al. [6] } \\
(2015)\end{array}$ & $1 / F$ & Pakistan & $\begin{array}{l}\text { Upper } \\
\text { abdomen }\end{array}$ & $\begin{array}{l}\text { Single serpiginous } \\
\text { lesion with } \\
\text { surrounding multiple } \\
\text { erythematous } \\
\text { papules. }\end{array}$ & $\mathrm{N} / \mathrm{A}$ & $\begin{array}{l}\text { Oral albendazole (200 } \\
\text { mg/day for } 3 \text { days) }\end{array}$ & $\begin{array}{c}\text { Complete resolution } \\
\text { after } 1 \text { week }\end{array}$ \\
\hline $\begin{array}{c}\text { Fischer et al. [1] } \\
(2016)\end{array}$ & $34 / F$ & $\begin{array}{l}\text { Malaysia, } \\
\text { Thailand }\end{array}$ & Right foot & $\begin{array}{l}\text { Single pruritic, } \\
\text { erythematous lesion } \\
\text { with torturous track. }\end{array}$ & $\mathrm{N} / \mathrm{A}$ & $\begin{array}{l}\text { Ivermectin cream (10 } \\
\mathrm{mg} / \mathrm{g} \text { ) twice daily. }\end{array}$ & $\begin{array}{c}\text { Complete resolution } \\
\text { after } 14 \text { days }\end{array}$ \\
\hline
\end{tabular}


Citation: Borda LJ, Kallis PJ, Griffith RD, Giubellino A, Cho-Vega JH. Hookworm-related Cutaneous Larva Migrans with Exceptional Multiple Cutaneous Entries. J Clin Investigat Dermatol. 2017;5(1): 4.

enzymes in up to $15 \%$ of the patients. Furthermore, administration of ivermectin consists of $200 \mathrm{mcg} / \mathrm{kg}$ once daily for one or two days with a cure rate of 94 to $100 \%$ in a single dose and pruritus, tachycardia, eosinophilia, and increased liver enzymes as side effects $[23,24]$. Topical application of thiabendazole 10 to $15 \%$ three times daily for 15 days can be used for localized presentations [8,17,21]. Use of liquid nitrogen (cryotherapy) at the leading edge of the skin track can be taken into consideration only in small, single lesions of HrCLM; however, is painful and usually ineffective since the larva is generally situated beyond the end of the track $[2,10,21]$, therefore is not recommended. Since our patient had multiple uncomplicated lesions, systemic treatment was indicated, with early resolution of the lesions after treatment. However, the multiple infestation sites seen in our patient should not suggest an increase in the treatment dosage since this extensive presentation seems to respond well to standard therapy, as seen in a previous case report [16].

Some suggestions for disease prevention include avoiding contact of bare skin with contaminated soil by coating the ground with impermeable material while sitting or lying, the use of footwear, preventing walking on bare feet and forbidding dogs and cats at beach areas [10]

\section{Conclusion}

HrCLM is a fairly prevalent cutaneous parasitic infestation affecting tropical and subtropical areas including South Florida. The infestation is acquired through direct inoculation with Ancylostoma braziliense or Ancylostoma caninum larvae in contaminated soil or sand, and is thus frequently seen in the homeless population. The diagnosis of HrCLM is often clinical, though varying presentations are possible, such as its presence of multiple larva entries seen in our case. HrCLM is self-limited in immunocompetent people, though oral and topical anti-helminthic agents such as albendazole and ivermectin are used to shorten the course of disease and prevent subsequent complications.

\section{References}

1. Fischer S, Nenoff P (2016) Cutaneous larva migrans: Successful topical treatment with ivermectin - a case report. J Dtsch Dermatol Ges 14: 622-623.

2. Kudrewicz K, Crittenden KN, Himes A (2015) A case of cutaneous larva migrans presenting in a pregnant patient. Dermatol Online $\mathrm{J} 21$.

3. Tekely E, Szostakiewicz B, Wawrzycki B, Kadziela-Wypyska G, JuszkiewiczBorowiec M, et al. (2013) Cutaneous larva migrans syndrome: A case report. Postepy Dermatol Alergol 30: 119-121.

4. Eichelmann K, Tomecki KJ, Martinez JD (2014) Tropical dermatology: Cutaneous larva migrans, gnathostomiasis, cutaneous amebiasis and trombiculiasis. Semin Cutan Med Surg 33: 133-135.
5. Lesniak R (2008) Cutaneous larva migrans. Dermatol Nurs 20: 471-472

6. Purkait R, Das S, Patra S (2015) Cutaneous larva migrans on upper abdomen: An unusual site. J Coll Physicians Surg Pak 25: 710.

7. Baple K, Clayton J (2015) Hookworm-related cutaneous larva migrans acquired in the UK. BMJ Case Rep 2015.

8. Caumes E (2000) Treatment of cutaneous larva migrans. Clin Infect Dis 30: 811-814.

9. Berlin JM, Goldberg SJ, McDonough RD, Leeman DR (2010) JAAD grand rounds quiz. Serpiginous eruption on the leg. J Am Acad Dermatol 63: 921 922.

10. Upendra Y, Mahajan VK, Mehta KS, Chauhan PS, Chander B (2013) Cutaneous larva migrans. Indian J Dermatol Venereol Leprol 79: 418-419.

11. Hochedez P, Caumes E (2007) Hookworm-related cutaneous larva migrans. J Travel Med 14: 326-333.

12. Siriez JY, Angoulvant F, Buffet P, Cleophax C, Bourrat E (2010) Individual variability of the cutaneous larva migrans (CLM) incubation period. Pediatr Dermatol 27: 211-212.

13. Jackson A, Heukelbach J, Calheiros CM, Soares Vde L, Harms G, et al (2006) A study in a community in Brazil in which cutaneous larva migrans is endemic. Clin Infect Dis 43: e13-e18.

14. Gutte R, Khopkar U (2011) Cutaneous larva migrans (creeping eruption). Indian Dermatol Online J 2: 48.

15. Purdy KS, Langley RG, Webb AN, Walsh N, Haldane D (2011) Cutaneous larva migrans. Lancet 377: 1948.

16. Malvy D, Ezzedine K, Pistone T, Receveur MC, Longy-Boursier M (2006) Extensive cutaneous larva migrans with folliculitis mimicking multimetameric herpes zoster presentation in an adult traveler returning from Thailand. $J$ Travel Med 13: 244-247.

17. Prickett KA, Ferringer TC (2015) What's eating you? Cutaneous larva migrans. Cutis 95: 126-128.

18. Langley RW, Haldane D, Purdy K, Walsh N (2011) Confocal microscopy of cutaneous larva migrans. J Am Acad Dermatol 64.

19. Zalaudek I, Giacomel J, Cabo H, Di Stefani A, Ferrara G, et al. (2008) Entodermoscopy: A new tool for diagnosing skin infections and infestations. Dermatology 216: 14-23.

20. Caumes E, Danis M (2004) From creeping eruption to hookworm-related cutaneous larva migrans. Lancet Infect Dis 4: 659-660.

21. Nelson SA, Warschaw KE (2012) Protozoa and worms. In: Bolognia JL, Jorizzo JL, Schaffer JV (Eds), Dermatology, $\left(3^{\text {rd }}\right.$ edn). Elsevier Health Sciences, UK, 1: 1391-1422.

22. Hotez PJ, Brooker S, Bethony JM, Bottazzi ME, Loukas A, et al. (2004) Hookworm infection. N Engl J Med 351: 799-807.

23. Schuster A, Lesshafft H, Reichert F, Talhari S, de Oliveira SG, et al. (2013) Hookworm-related cutaneous larva migrans in northern Brazil: Resolution of clinical pathology after a single dose of ivermectin. Clin Infect Dis 57: 11551157.

24. Hochedez P, Caumes E (2008) Common skin infections in travelers. J Trave Med 15: 252-262.

25. Roest MA, Ratnavel R (2001) Cutaneous larva migrans contracted in England: A reminder. Clin Exp Dermatol 26: 389-390. 